\title{
Combination of betulinic acid with diazen-I-ium- I,2-diolate nitric oxide moiety donating a novel anticancer candidate
}

This article was published in the following Dove Press journal:

OncoTargets and Therapy

\author{
Laiyin Zhang' \\ Shuangxing $\mathrm{Hou}^{2}$ \\ Bo $\mathrm{Li}^{3}$ \\ Jianjian $\operatorname{Pan}^{4}$ \\ Liping Jiang ${ }^{5}$ \\ Guiying Zhou ${ }^{2}$ \\ Hong $\mathrm{Gu}^{6}$ \\ Caixing Zhao ${ }^{6}$ \\ Huiping $L^{6}$ \\ Fenfen $\mathrm{Ma}^{6}$ \\ 'Department of Pharmacy, Linyi \\ People's Hospital, Linyi, ${ }^{2}$ Department \\ of Neurology, Shanghai Pudong \\ Hospital, Fudan University Pudong \\ Medical Center, ${ }^{3}$ Department of \\ Hand Surgery, Huashan Hospital, \\ Fudan University, ${ }^{4}$ Department \\ of General Medicine, Fudan \\ University, ${ }^{5}$ Department of \\ Physiology and Pathophysiology, \\ Shanghai Medical College, Fudan \\ University, ${ }^{6}$ Department of Pharmacy, \\ Pudong Hospital, Fudan University, \\ Shanghai, China
}

Background: Betulinic acid (BA) is a complex lupane triterpenoid with unique antineoplastic activity. However, its antiproliferative activity is far from satisfaction. In order to improve its anticancer efficacy, betulinic acid was conjugated with a nitric oxide (NO)-releasing moiety to get a novel hybrid, BA-78.

Methods: The antiproliferative activity of BA-78 against 6 cell lines and the ability of releasing nitric oxide were determined. The pro-apoptosis mechanism of BA-78 was investigated as well. Results: BA-78 exhibited time-dependent release of NO, and it displayed higher antiproliferative potential than BA through increasing apoptosis and inducing cell cycle arrest at G1 phase. Western blotting results showed that BA-78 increased the expression of Bax, Bid, Bad and cytochrome $\mathrm{C}$ and reduced the level of anti-apoptosis proteins including $\mathrm{Bcl}-2$ and $\mathrm{Bcl}-\mathrm{xl}$.

Conclusion: Our study revealed that novel compound BA-78, possessing betulinic acid and nitric oxide (NO)-releasing moiety, could be developed as an antitumor agent.

Keywords: lupane triterpenoid, nitric oxide, anticancer, apoptosis, NONOate, Bcl-2 family

\section{Introduction}

Natural products have always been the main source of anticancer drugs, especially in the treatment of solid tumors, against which targeted therapies have shown disappointing efficiency. ${ }^{1}$ Betulinic acid (BA) (Figure 1), isolated from the root of Pulsatilla chinensis (Bge) has long been used in traditional treatments. ${ }^{2}$ BA exhibits multiple biological activities, including anti-tumor, anti-HIV and antiangiogenesis, ${ }^{3,4}$ among which, its unique, safe and remarkable anticancer pharmacological profile is of particular interest. ${ }^{5}$ It is generally accepted that the apoptotic events induced by BA were associated with apoptosis-related proteins. ${ }^{6}$ It activates the mitochondrial pathway of apoptosis, which results in the release of cytochrome c (Cyt-c). ${ }^{7}$ However, the development of BA for cancer therapy is hampered largely by its modest efficacy and broad range of pharmacological activity. Therefore, it is highly desirable to develop novel derivatives of BA to improve its cytotoxic potency while reducing its side effects.

Nitric oxide (NO) is a gas signaling molecule, which plays multiple roles in physiological conditions or under pathologic processes. ${ }^{8}$ Studies have shown that high level of NO cannot only induce apoptosis of tumor cells, but can also sensitize tumor cells to chemotherapy. ${ }^{9}$ However, limited by the gas property of NO, NO donors are alternatively used as surrogates for NO in anticancer studies. Diazeniumdiolates (NONOates) are considered as reliable sources of $\mathrm{NO}^{10}{ }^{10}$ as shown in Figure 2, NONOate prodrugs

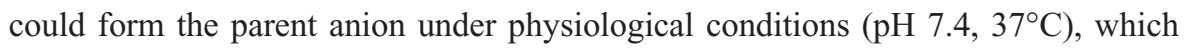




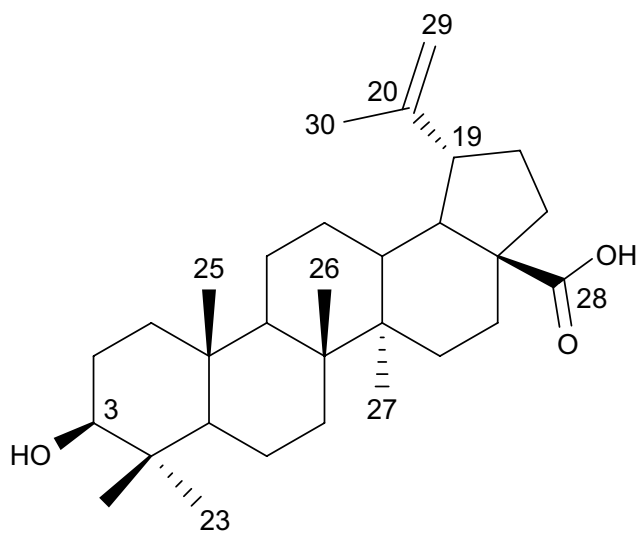

Figure I Chemical structure of betulinic acid.

further decomposes to release 2 molecules of NO. Recently, abundant NONOate-based hybrids have been developed as anticancer agents, including PABA/NO (2), JS-K (3), 5-Fu/ NO (4), and oridonin/NO (5) (Figure 2). ${ }^{11-14}$ It was observed that the derivatives releasing higher amount of NO showed superior antiproliferative activity, suggesting that $\mathrm{NO}$ was a component of the cytostatic effects of such kind of hybrids.

Encouraged by these findings, we designed and synthesized a novel hybride (BA-78) containing BA and NONOate moieties to improve the antiproliferative activity of natural BA. Herein, we report the synthesis, in vitro antiproliferative activity and NO release ability of BA-78, and evaluate its possible mechanism of action.

\section{Materials and methods Materials}

Mouse melanoma cells (B16F10), human breast cancer cells (MCF-7), human colon cancer cells (HCT-116), human adenocarcinomic alveolar basal epithelial cells (A549), human hepatocarcinoma (HepG2) and human embryonic lung fibroblast (Helf) were purchased from American Type Culture Collection (Manassas, VA, USA). 3-[4,5-dimethylthiazol-2yl]-2,5-diphenyl-tetrazolium bromide (MTT) and propidium iodide (PI) were purchased from Sigma Chemical Co. (St Louis, MO, USA). The Annexin V-fluorescein isothiocyanate (FITC) apoptosis detection kit was purchased from BD Parmingen (San Diego, CA, USA). Griess reagent was purchased from Beyotime (Jiangsu, China). Primary antibodies against Bax, Bcl-xl, Bak, Bid, Bad, Bcl-2, Cyt-c and $\beta$-actin were purchased from Cell Signaling Technology, (Boston, MA, USA) and fluorescent secondary antibodies (goat-anti-rabbit or goat-anti-mouse) were purchased from Life Technologies (Grand Island, NY, USA). All cell culture reagents, including no-essential amino acids and the bicinchoninic acid (BCA) protein assay kit were purchased from Life Technologies.

\section{Chemistry}

All commercially available solvents and reagents were used without further purification. Flash column chromatography was carried out on 200-300 mesh silica gel. ${ }^{1} \mathrm{H}$ nuclear

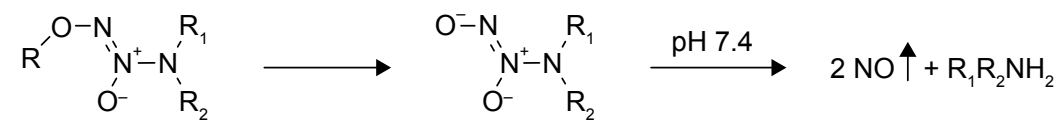<smiles>CNc1ccc(C(=O)Oc2cc(O/N=[N+](\[O-])N(C)C)c([N+](=O)[O-])cc2[N+](=O)[O-])cc1</smiles>

PABA/NO (2)

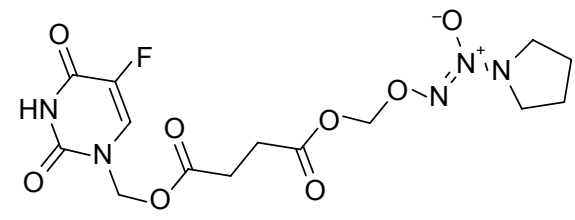

$5-\mathrm{Fu} / \mathrm{NO}(4)$<smiles>CCC(=O)N1CCN([NH+]([O-])NOc2ccc([N+](=O)[O-])cc2[N+](=O)[O-])CC1</smiles>

JS-K (3)

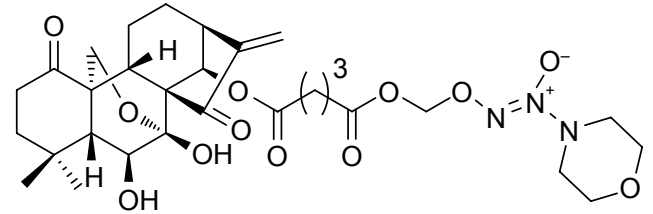

Oridonin/NO (5)

Figure 2 Mechansim of NO release from diazeniumdiolate and the structures of PABA/NO (2), JS-K (3), 5-Fu/NO (4), and oridonin/NO (5). Abbreviation: NO, nitric oxide. 
magnetic resonance (NMR) and ${ }^{13} \mathrm{C}$ NMR spectra were recorded with a Bruker AV-300 spectrometer in the indicated solvents (trimethylchlorosilane [TMS] as internal standard). Mass spectra were obtained using FTMS-2000. The synthetic method and physicochemical date of compounds 6 and 9 have been disclosed in previous reports, the NMR spectrums of compounds 7, 8, and 10 are available in Figures S1-S3. ${ }^{15,16}$

\section{$\mathrm{O}^{2}$-(Methylthiomethyl)- I-(pyrrolidin- I-yl) diazen-I -ium-I,2-diolate (7)}

The sodium NONOate $6(6.88 \mathrm{~g}, 45.0 \mathrm{mmol})$ was added to a suspension of sodium carbonate $(4.78 \mathrm{~g}, 45.0 \mathrm{mmol})$ and dimethylformamide (DMF) $(100 \mathrm{~mL})$ at room temperature, and this mixture was stirred for $10 \mathrm{~min}$. Chloromethyl methyl sulfide $(3.72 \mathrm{~mL}, 45.0 \mathrm{mmol}$ ) was added dropwise, and the reaction was allowed to proceed at room temperature for $4 \mathrm{~h}$ with stirring. Ethyl acetate $(200 \mathrm{~mL})$ was added to quench the reaction, the solids were filtered off, the organic phase was washed with water $(5 \times 60 \mathrm{~mL})$, and dried with $\mathrm{Na}_{2} \mathrm{SO}_{4}$. The solvent was removed in vacuo to give a liquid residue, which was purified by silica gel column chromatography using EtOAc/hexane $(1: 4, \mathrm{v} / \mathrm{v})$ as the eluent. Compound 7 was obtained as a canary yellow liquid (3.80 g, 45\%): ${ }^{1} \mathrm{H}$ NMR (300 MHz, $\left.\mathrm{CDCl}_{3}\right): \delta(\mathrm{ppm}) 5.15(\mathrm{~s}, 2 \mathrm{H}), 3.53-3.48(\mathrm{~m}, 4 \mathrm{H})$, 2.21 (s, 3 H), 1.91-1.86 (m, 4 H).

\section{$\mathrm{O}^{2}$-Chloromethyl- I-(pyrrolidin- I-yl) diazen-I-ium-I,2-diolate (8)}

A solution of compound $7(273 \mathrm{mg}, 1.44 \mathrm{mmol})$ in dry dichloromethane $(30 \mathrm{~mL})$ was cooled to $0^{\circ} \mathrm{C}$ and sulfuryl chloride (1.44 mL, 1.0 M solution in dichloromethane) was added dropwise, the ice bath was removed and the reaction mixture was stirred at room temperature for another $2 \mathrm{~h}$. The solvent was evaporated to afford compound 8 in nearly quantitative yield, which was used without further purification. ${ }^{1} \mathrm{HNMR}\left(300 \mathrm{MHz}, \mathrm{CDCl}_{3}\right.$ ): $\delta$ (ppm) 5.80 (s, $\left.2 \mathrm{H}\right), 3.63$ (m, $4 \mathrm{H}), 1.95$ (m, $4 \mathrm{H})$.

\section{BA-78}

To a solution of $0.1 \mathrm{~g}, 9 \mathrm{mmol}$ in anhydrous DMF was added $\mathrm{Cs}_{2} \mathrm{CO}_{3}$ (1 eq.) and compound 8 (1.2 eq.). The reaction was stirred at room temperature for $6 \mathrm{~h}$. The reaction mixture was diluted with $20 \mathrm{~mL}$ of ethyl acetate, and the organic layer was separated. The aqueous layer was extracted with ethyl acetate $(2 \times 10 \mathrm{~mL})$. The combined organic layer was dried over anhydrous sodium sulfate, and the solvent was evaporated under reduced pressure. The crude material was purified by flash column chromatography (1:1 hexane/ethyl acetate) to afford product $10(51 \%)$ as a white solid. ${ }^{1} \mathrm{H}-\mathrm{NMR}\left(\mathrm{CDCl}_{3}\right.$, $300 \mathrm{MHz}$ ): $\delta 0.73,0.84,0.90,0.97,1.68$ (each $3 \mathrm{H}, \mathrm{s}), 1.59$ (m, 4 H), 1.98 (2 H, m), 2.24 (2 H, m), 3.01 (1 H, m), 3.49 (4 H, t), 3.81, 4.01 (each $1 \mathrm{H}, \mathrm{m}), 4.59,4.72$ (each $1 \mathrm{H}, \mathrm{m}), 5.80$ $(2 \mathrm{H}, \mathrm{s}) ;{ }^{13} \mathrm{C}-\mathrm{NMR}\left(\mathrm{CDCl}_{3}, 75 \mathrm{MHz}\right): \delta 15.9,16.6,18.1$, 19.3, 20.8, 15.4, 26.2, 29.7, 29.8, 30.6, 31.1, 32.3, 37.0, 38.3, $38.5,39.2,40.6,40.8,42.1,42.4,45.1,46.9,49.2,50.5,56.3$, $67.2,72.1,96.5,109.6,152.8,173.4,179.7$; mass spectrometry (MS) electrospray ionization (ESI) $m / z[\mathrm{M}+\mathrm{H}]^{+}$642.4, high resolution mass spectrometer (HRMS) (ESI) $\mathrm{m} / \mathrm{z}$ calculated for $\mathrm{C}_{37} \mathrm{H}_{63} \mathrm{~N}_{4} \mathrm{O}_{6}\left[\mathrm{M}+\mathrm{NH}_{4}\right]^{+} 659.4742$, found 659.4738 .

\section{Determination of in vitro antiproliferative activity}

The viability of 5 human cancer cell lines (B16F10, MCF-7, HCT-116, A549, and HepG2) treated with BA, BA-78, and Cisplatin, was determined using the MTT assay. Briefly, cells were seeded in 96-microwell plates, incubated at $37^{\circ} \mathrm{C}$ in a humidified incubator with $5 \% \mathrm{CO}_{2}$ for $24 \mathrm{~h}$ prior to the experiments. After removing the medium, $100 \mu \mathrm{L}$ of fresh medium containing the test compounds at 5 concentrations (ie, $10^{-4}, 10^{-5}, 10^{-6}, 10^{-7}$, and $10^{-8} \mathrm{M}$ ) were added to microtiter plates and cells were incubated with each compound at $37^{\circ} \mathrm{C}$ for another $72 \mathrm{~h}$. At the end of the incubation, the medium was discarded, cells were washed with PBS and $100 \mu \mathrm{L}$ of MTT buffer was added to each well. Cells were incubated with MTT for at least $4 \mathrm{~h}$ at $37^{\circ} \mathrm{C}$ and the viabilities were proportioned to the value of optical densities, which was quantitatively measured by spectrophotometry (Biorad, Nazareth, Belgium) at $570 \mathrm{~nm}$. The dose-response curve (not shown) was created by plotting the percent viability against the log of concentrations of the corresponding compound for each cell line. The molar concentrations that caused $50 \%$ cell killing $\left(\mathrm{IC}_{50}\right)$ were determined.

\section{Detection of NO production}

NO was indirectly determined by measuring nitrite content in the culture supernatant using Griess reagent. Briefly, B16F10 cells $\left(2 \times 10^{4}\right.$ cells $\left./ \mathrm{mL}\right)$ were seeded in a $96-$ well plate and incubated at $37^{\circ} \mathrm{C}$ for $24 \mathrm{~h}$ followed by incubation with $10 \mu \mathrm{M}$ of BA-78 for different times (ie, 10, 30, $60 \mathrm{~min}$, $3,6,12,24$, and $48 \mathrm{~h}$ ). For each well, $50 \mu \mathrm{L}$ of supernatants was collected in a tube, the collection was incubated with $25 \mu \mathrm{L}$ of sulfanilic acid for $10 \mathrm{~min}$ at room temperature in the dark. After the reaction, $25 \mu \mathrm{L}$ of $N$-(1-naphthyl) ethylenediamine was added into the tube and the plate was incubated for another $10 \mathrm{~min}$ at room temperature in the dark. The absorbance was read at $550 \mathrm{~nm}$ by a spectrophotometry 
(BioTek Instruments, Inc., Waltham, MA, USA). The amount of NO was quantified according to the standard curve prepared under the same condition and expressed as NO released/micromole of BA-87.

\section{Determination of apoptosis by flow cytometry}

B16F10 cells $\left(5 \times 10^{5}\right.$ cells $\left./ \mathrm{mL}\right)$ were seeded in 6-well plates and treated with BA-78 at different concentrations (ie, 0 , $0.25,0.5$, and $1.0 \mu \mathrm{M}$ ) for $36 \mathrm{~h}$. The cells were then washed twice and digested with trypsin. After centrifugation, the supernatants were removed and cells were resuspended in $500 \mu \mathrm{L}$ of $1 \times$ binding buffer to obtain a concentration of $1 \times 10^{6}$ cell $/ \mathrm{mL}$. Annexin V-FITC $5 \mu \mathrm{L}$ and PI $10 \mu \mathrm{L}$ were added and cells were incubated at room temperature for another $15 \mathrm{~min}$ in the dark. The stained cells were analyzed by a FC500 cytometer (Beckman Coulter, Brea, CA, USA).

\section{Western blot analysis}

B16F10 cells were incubated with BA-78 at different concentrations (ie, $0,0.25,0.5$, and $1.0 \mu \mathrm{M}$ ) for $48 \mathrm{~h}$. Cells were washed with cold PBS twice and lysed on ice for $10 \mathrm{~min}$, and lysates were centrifuged at $13,000 \mathrm{~g}$ for $15 \mathrm{~min}$. The protein concentration in the supernatant was determined using BCA protein assay. Equal amounts of protein were loaded and separated using sodium dodecyl sulfate polyacrylamide gel electrophoresis (SDS-PAGE) and transferred to polyvinylidene fluoride (PVDF) membrane. Membranes were blocked for $1 \mathrm{~h}$ at room temperature with $5 \%$ bovine serum albumin and then were incubated with primary antibodies against Bax, Bad, Bid, Bak, Bcl-xl, Bcl-2, cytochrome c, caspase-3 and $\beta$-actin (all purchased from Cell Signaling
Technology) overnight at $4^{\circ} \mathrm{C}$. After the membranes were washed, they were then incubated with fluorescent secondary antibodies for $60 \mathrm{~min}$ at room temperature. The membranes were washed and proteins were detected with LI-COR Odyssey Infrared Imaging System.

\section{Cell cycle analysis}

$5 \times 10^{4}$ B16F10 cells were seeded into 6-well plates and incubated overnight. After incubation with various concentrations of BA-78 for $48 \mathrm{~h}$, cells were harvested, washed with cold PBS and fixed with $70 \%$ ethanol in $\mathrm{PBS}$ at $-20^{\circ} \mathrm{C}$ for $12 \mathrm{~h}$. Subsequently, the cells were resuspended in PBS containing $100 \mu \mathrm{g} / \mathrm{mL}$ RNase and $50 \mu \mathrm{g} / \mathrm{mL}$ PI and incubated at $37^{\circ} \mathrm{C}$ for $30 \mathrm{~min}$. Cell cycle distribution of nuclear DNA was determined by flow cytometry on a FC500 cytometer (Beckman Coulter).

\section{Statistical analysis}

Data were expressed as mean \pm standard error of the mean. Data with normal distribution were analyzed by $t$-test or oneway analysis of variance non-parametric analysis followed by the Bonferroni post hoc test. Data with abnormal distribution were analyzed by Kruskal-Wallis test (GraphPad 5.0). $P<0.05$ was considered statistically significant.

\section{Results}

\section{Chemistry}

As shown in Scheme 1, the synthesis of NONOates was carried according to the literature in the presence of nanometersized $\mathrm{TiO}_{2} \cdot{ }^{16}$ Briefly, reaction of pyrrolidine with $\mathrm{NO}$ gas at room temperature under atmospheric pressure afforded $O^{2}$-sodium-1-(pyrrolidin-1-yl)diazen-1-ium-1,2-diolates (6)
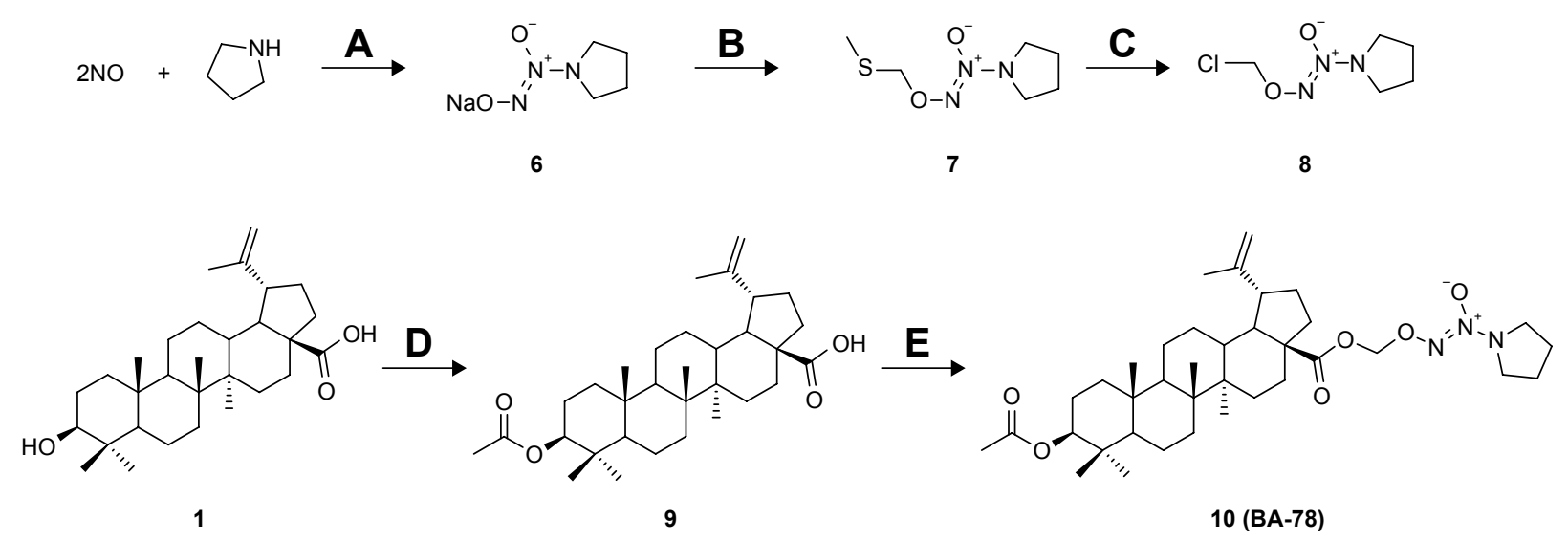

Scheme I Synthetic route for hybride (BA-78).

Notes: Reagents and conditions: (A) MeONa, MeOH, nanometers-sized TiO, rt, 54 h, $78 \%$; (B) $\mathrm{ClCH}_{2} \mathrm{SCH}_{3}, \mathrm{DMF} \mathrm{Na}_{2} \mathrm{CO}_{3}, \mathrm{rt}, 3 \mathrm{~h} 45 \%$; (C) SO $\mathrm{Cl}_{2}, \mathrm{DCM}, \mathrm{rt}, 2 \mathrm{~h}, 98 \%$; (D) $\mathrm{Ac}_{2} \mathrm{O}$, DMAP, pyridine, rt, $2 \mathrm{~h}, 92 \%$; (E) 8, $\mathrm{Cs}_{2} \mathrm{CO}_{3}$, DMF, rt, $6 \mathrm{~h}, 51 \%$.

Abbreviations: DCM, dichloromethane; DMAP, dimethylaminopyridine; DMF, dimethylformamide. 
in $78 \%$ yield. The sodium salts were alkylated with chloromethyl methyl sulfide to afford $O^{2}$-(methylthiomethyl)1-(pyrrolidin-1-yl)diazen-1-ium-1,2-diolates (7), which were subsequently reacted with sulfuryl chloride in dichloromethane to afford the $O^{2}$-chloromethyl-protected NONOate (8). This preparative approach of NONOates under atmospheric pressure using easily available apparatus promoted the following synthesis of BA-78. Next, acetylated BA (9) was prepared by using acetic anhydride in $92 \%$ yield, which subsequently reacted with NONOate (8) to afford the target compound 10 (BA-78) in yield of $51 \%$.

\section{Cytostatic effects of BA-78 against human cancer cells}

With BA-78 in hand, we first evaluated its cytotoxicity on cancer cell by MTT method. As shown in Table 1, BA-78 displayed preferred inhibitory efficacies than BA against the selected malignant cell lines, with $\mathrm{IC}_{50}$ values ranging from 0.89 to $7.44 \mu \mathrm{M}$. The most sensitive cancer cell line was B16F10, against which the $\mathrm{IC}_{50}$ value of BA-78 was $0.89 \mu \mathrm{M}$, which were even lower than that of positive control cisplatin. This is in line with reports that BA is more potent against melanoma. In addition, similar experiments were performed with the Helf and human normal liver cells (L02). The results showed that BA-87 had little inhibiting effects on the growth of Helf and L02 cells; the $\mathrm{IC}_{50}$ values on Helf and L02 cells were much higher than that on cancer cells. From the growth response curves (Supplementary materials) of BA-78 on these cells at a concentration of $1 \mu \mathrm{M}$, it can be inferred that the growth of Helf and L02 cells were not affected at all, while the growth of tumor cells were affected significantly. These data suggested that BA-78 has selective cancer cell killing properties, and will be safe for cancer treatment.

\section{Nitrogen oxide-releasing efficacy of BA-78}

The NO-releasing efficacy has been proven to be an important component for the antiproliferative activity of NO-based hybrids. ${ }^{17}$ Using Griess assay, we tried to characterize the NO release in cancer cells and identify the correlation between NO production level and cytotoxicity of BA-87. As shown in Figure $3 \mathrm{~A}, \sim 80 \%$ of nitrite/nitrate was detected in the supernatant of B16F10 cell culture subjected with BA-78 after $12 \mathrm{~h}$, suggesting that NO might be a key factor in the cytotoxicity of such hybride. Furthermore, the cytotoxicity of components 8,9 , and their equimolar combination $(8+9)$ were tested against B16F10 cells (Figure 3B). As expected, the $\mathrm{IC}_{50}$ values of components 8,9 , and their combination were significantly higher than that of BA-87 (Figure 3C). Previous results suggested that the antiproliferative activity of BA-78 was attributed to the synergic effects of BA and NO donor moieties.

\section{BA-78 increased level of cell apoptosis}

High level of NO is toxic and able to induce apoptosis of tumor cell. ${ }^{18}$ To investigate whether BA-87 can induce cell apoptosis, B16F10 cells were incubated with $0,0.25$, 0.5 , and $1.0 \mu \mathrm{M}$ of BA-78 and Annexin V-FITC/PI double staining was applied to test cell apoptosis at the end of the incubation. Annexin $\mathrm{V}$ is a phospholipid-binding protein with strong affinity for phosphatidylserine, which appears on the cell surface as a general indicator of apoptosis. As shown in Figure 4, BA-78 dose dependently increased the percentage of Annexin V-positive cells (right quadrants, Q2+Q3) ranging from $8.27 \%(0.25 \mu \mathrm{M})$ to $22.15 \%(1 \mu \mathrm{M})$, which were significantly higher than the basement apoptosis rate in control cells (only $4.25 \%$ ). Table 2 shows the percentages of early apoptosis cells (Q3) and advanced apoptosis cells (Q2).

\section{BA-78 reduced level of anti-apoptosis proteins and increased level of pro- apoptosis proteins}

The previous flow cytometry results indicated the proapoptosis activity of BA-78. We further evaluated the results by detecting the expression of apoptosis-related proteins.

Table I Antiproliferative activities of BA-78 against different cell lines

\begin{tabular}{|c|c|c|c|c|c|c|c|}
\hline \multirow[t]{2}{*}{ Compounds } & \multicolumn{7}{|c|}{ Cell lines $\left(I C_{50}, a M \pm S E M\right)$} \\
\hline & BI6FIO & MCF-7 & HCT-I I 6 & A549 & HepG2 & Helf & L02 \\
\hline $\mathrm{BA}$ & $26.98 \pm 2.50$ & $17.53 \pm 1.72$ & $27.3 \pm 3.28$ & $38.30 \pm 5.90$ & $30.40 \pm 5.14$ & $61.99 \pm 8.61$ & $96.32 \pm 7.99$ \\
\hline BA-78 & $0.89 \pm 0.14$ & $0.92 \pm 0.09$ & $1.53 \pm 0.24$ & $7.44 \pm 0.98$ & $4.32 \pm 0.73$ & $17.76 \pm 0.88$ & $27.21 \pm 3.18$ \\
\hline Cisplatin & 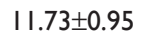 & $7.83 \pm 0.52$ & $9.45 \pm 1.04$ & $12.67 \pm 1.85$ & $4.77 \pm 0.62$ & $21.75 \pm 3.03$ & $9.17 \pm 0.83$ \\
\hline
\end{tabular}

Notes: ${ }^{\circ}$ MTT methods, cells were incubated with indicated compounds for $72 \mathrm{~h}$ (mean $\pm \mathrm{SEM}, \mathrm{n}=3$ ). $\mathrm{IC}_{50}$ represents the concentration that caused $50 \%$ cell killing. Abbreviations: A549, human adenocarcinomic alveolar basal epithelial cells; BI6FI0, mouse melanoma cells; BA, betulinic acid; BA-78, synthetic route for hybride; HCT-I16, human colon cancer cells; Helf, human embryonic lung fibroblast; HepG2, human hepatocarcinoma; L02, liver cells; MCF-7, human breast cancer cells; SEM, standard error of the mean. 


\section{A $(\mu \mathrm{M} / \mu \mathrm{M})$}

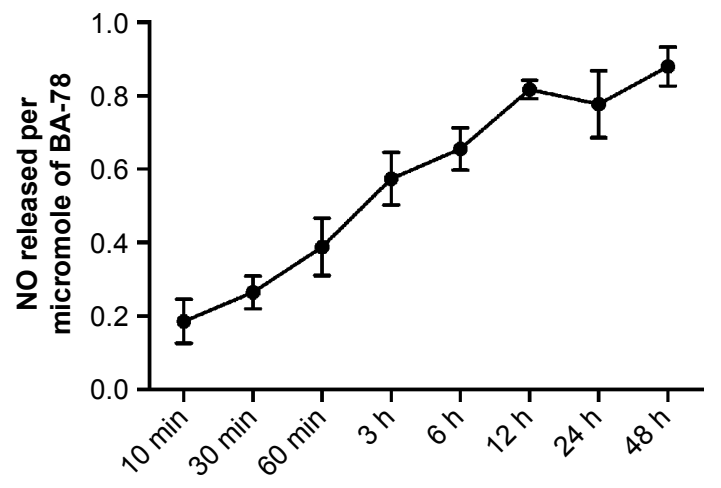

B

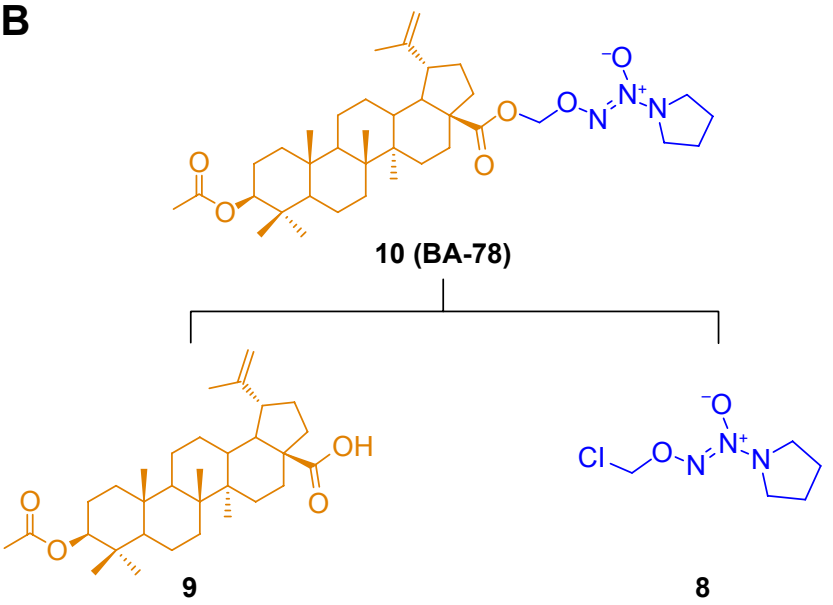

C

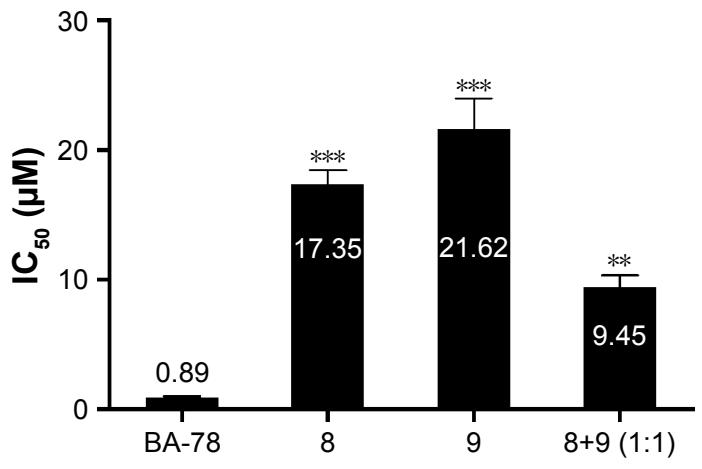

Figure 3 Time-dependent production of $\mathrm{NO}$ in BI6FIO cells.

Notes: (A) BI6FI0 cells were incubated with $10 \mu \mathrm{M}$ of BA-78 for $48 \mathrm{~h}$, and concentrations of NO in cultural medium were determined at different time points. Data represents level of NO produced by per micromole of BA-78; (B) Structure of components 8 and 9, and BA-78; (C) Comparison of antiproliferative activity of BA-78 with its components 8,9 , and the equimolar mixture of 8 and 9 . Data were average of 3 independent experiments. $* * P<0.01$ versus control group, $* * * P<0.00 \mathrm{I}$ versus control group. $I C_{50}$ represents the concentration that caused $50 \%$ cell killing.

Abbreviations: BI6FI0, mouse melanoma cells; BA-78, synthetic route for hybride; NO, nitric oxide.

The Bcl-2 family of proteins determines cell fate by regulating the integrity of the mitochondrial outer membrane (MOM). It includes adaptor proteins only containing BH3 domain such as Bim and Bid, which initiate apoptosis. The second group are prosurvival proteins (Bcl-2 and $\mathrm{Bcl}-\mathrm{xL}$ ), which inhibit the activation of a pro-apoptosis group consisting of Bax and Bak. The latter constitute the pore-like structures in the MOM, from which Cyt-c could be released and initiate mitochondrial apoptosis pathway. ${ }^{19}$ As shown in Figure 5A and B, the expression of pro-apoptotic proteins increased with the incubation of BA-78, while the expression of antiapoptotic proteins profoundly decreased. Furthermore, the cytosolic expression of Cyt-c, which plays a key role in the caspase-dependent apoptotic pathway, also increased after the treatment of BA-78. These results suggested that apoptotic pathway was involved in BA-78 induced cell death.

\section{BA-78 induced cell cycle arrest at GI phase}

Because mitochondrial dysfunction has a close relationship with events such as apoptosis, necrosis and cell cycle arrest, we further analyzed the effect of BA-78 on cell cycle of B16F10 cells. B16F10 cells were incubated with different concentrations of BA-78 (eg, 0, 0.25, 0.5 and $1.0 \mu \mathrm{M}$ ) for $36 \mathrm{~h}$, and after staining with PI, the cell cycle was analyzed by flow cytometry. As shown in Figure 6, BA-78 dose dependently increased the number of B16F 10 cells in G1 phase, suggesting that BA-78 could induce cell arrest at G1 phase. Accordingly, the number of cells in G2 phase reduced from $18.45 \%$ in control group to $4.84 \%$ in $1 \mu \mathrm{M}$ of BA-78 treatment group as displayed in Table 3, indicating that BA-87 redirected cells from mitotic phase to quiescent stage. Taken together, these data showed that the anti-proliferation activity of BA-78 against cancer 

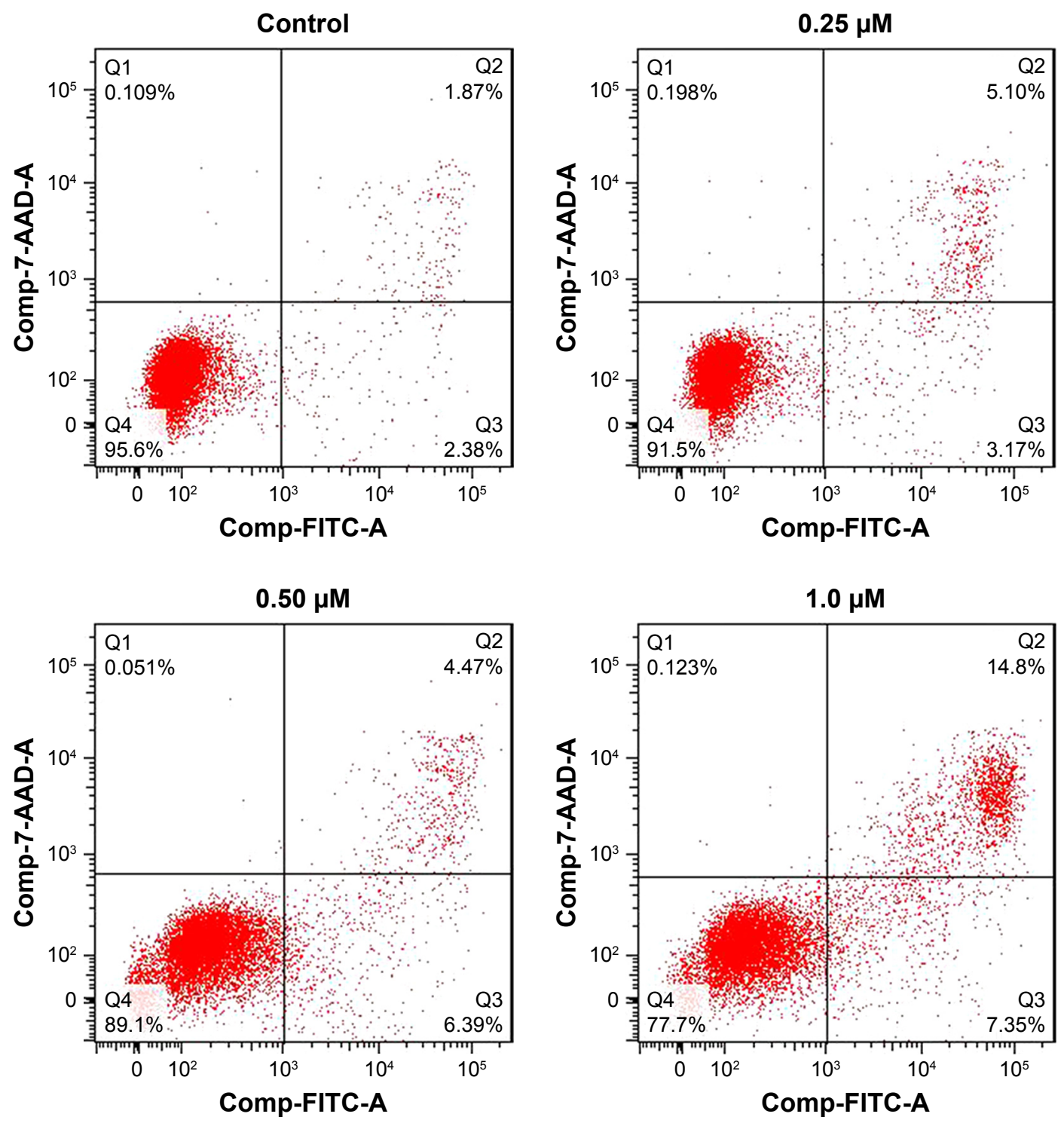

Figure 4 Effect of BA-78 on the induction of apoptosis in BI6FIO cells.

Note: Flow cytometric analysis was applied to determine the level of apoptosis in control group, BA-78 at $0.25,0.5$ and I.0 $\mu$ M. Abbreviations: BI6FI0, mouse melanoma cells; BA-78, synthetic route for hybride; FITC-A, fluorescein isothiocyanate-annexin.

cell was at least partially dependent on cell cycle arrest at G1 phase.

\section{Discussion}

BA is a naturally occurring pentacyclic triterpenoid, which has been used as an anticancer agent. ${ }^{20}$ In recent years,

Table 2 Flow cytometry analysis of apoptotic BI6FIO cells

\begin{tabular}{llllll}
\hline Group & & Q1 (\%) & Q2 (\%) & Q3 (\%) & Q4 (\%) \\
\hline Control & & 0.11 & 1.87 & 2.38 & 95.60 \\
BA-78 & $0.25 \mu \mathrm{M}$ & 0.20 & 5.10 & 3.17 & 91.50 \\
& $0.50 \mu \mathrm{M}$ & 0.05 & 4.47 & 6.39 & 89.10 \\
& $1.0 \mu \mathrm{M}$ & 0.12 & 14.80 & 7.35 & 77.70
\end{tabular}

Abbreviations: BI6FI0, mouse melanoma cells; BA-78, synthetic route for hybride. a number of structural modifications of BA have been carried out to improve its efficacy. ${ }^{21}$ The positions of C-1, C-2, C-3, C-4, C-20 and C-28 are the diversity centers of BA, and some derivatives resulted from structural modifications at these positions exhibited potent anticancer activities. ${ }^{22-24}$ Rational design of pharmacological agents by connecting NO donors takes account of specific modifications of known molecules with the purpose of optimizing their efficacy and safety. ${ }^{25-28}$ NO-releasing derivatives of BA have been reported previously, a series of compounds were synthesized by connecting BA with furoxan NO donors, and they exhibited obvious cytotoxicity against human hepatocellular carcinoma cells in vitro. ${ }^{29}$ In the present study, we successfully prepared a 

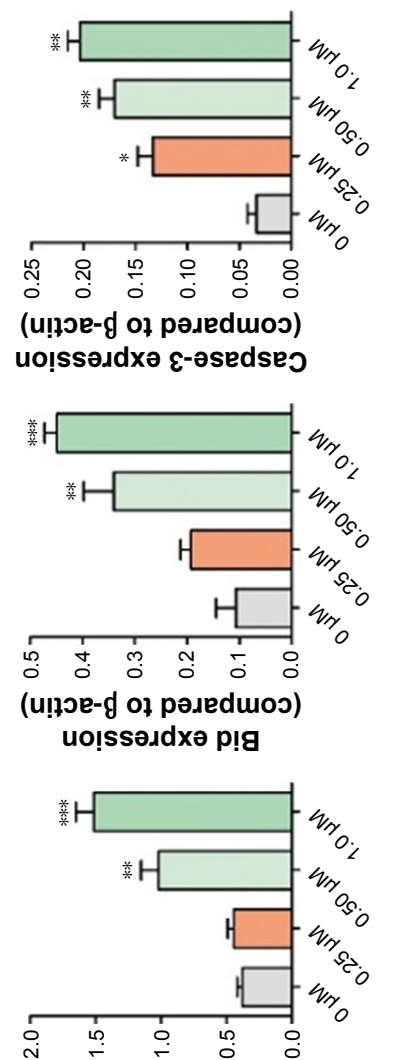

(u!foe-d of pojeduoo)

uo!̣ssəddxə peg
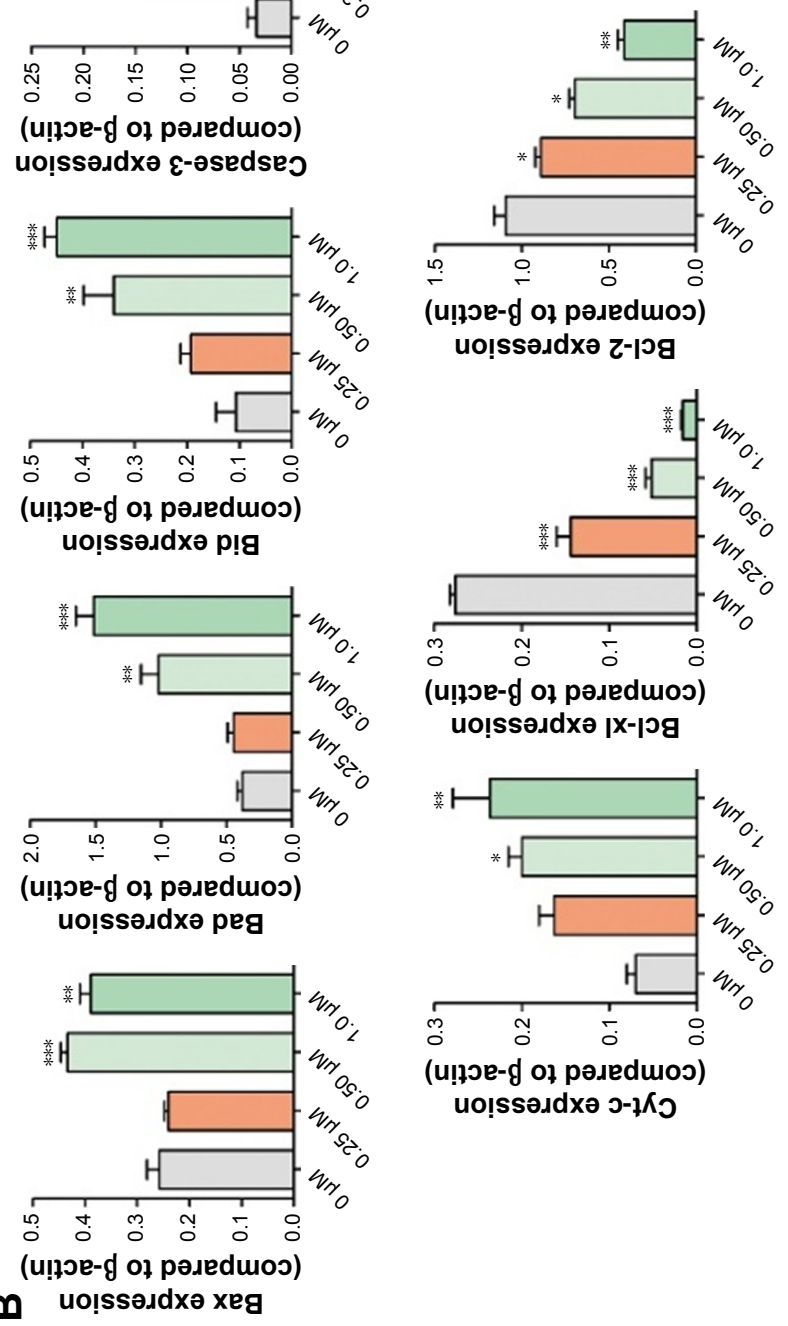

uo!ssəגdxə 乙-ן尸্g

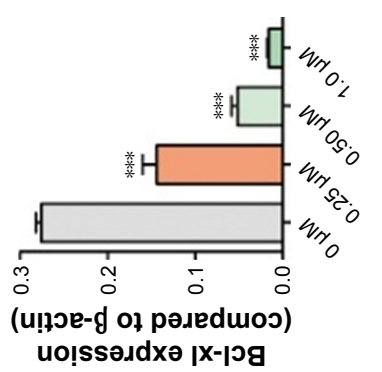

uo!̣ss.dxə |x-ןog
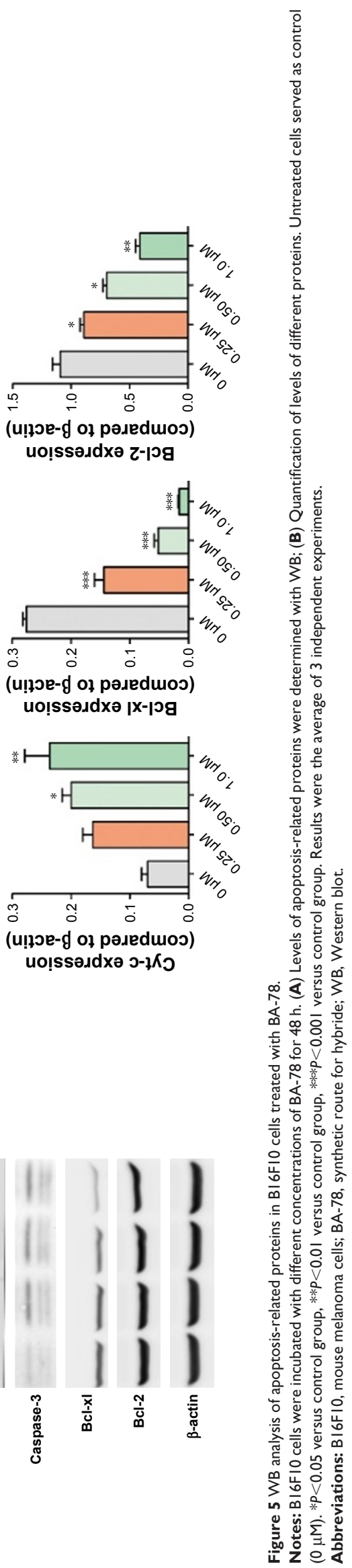

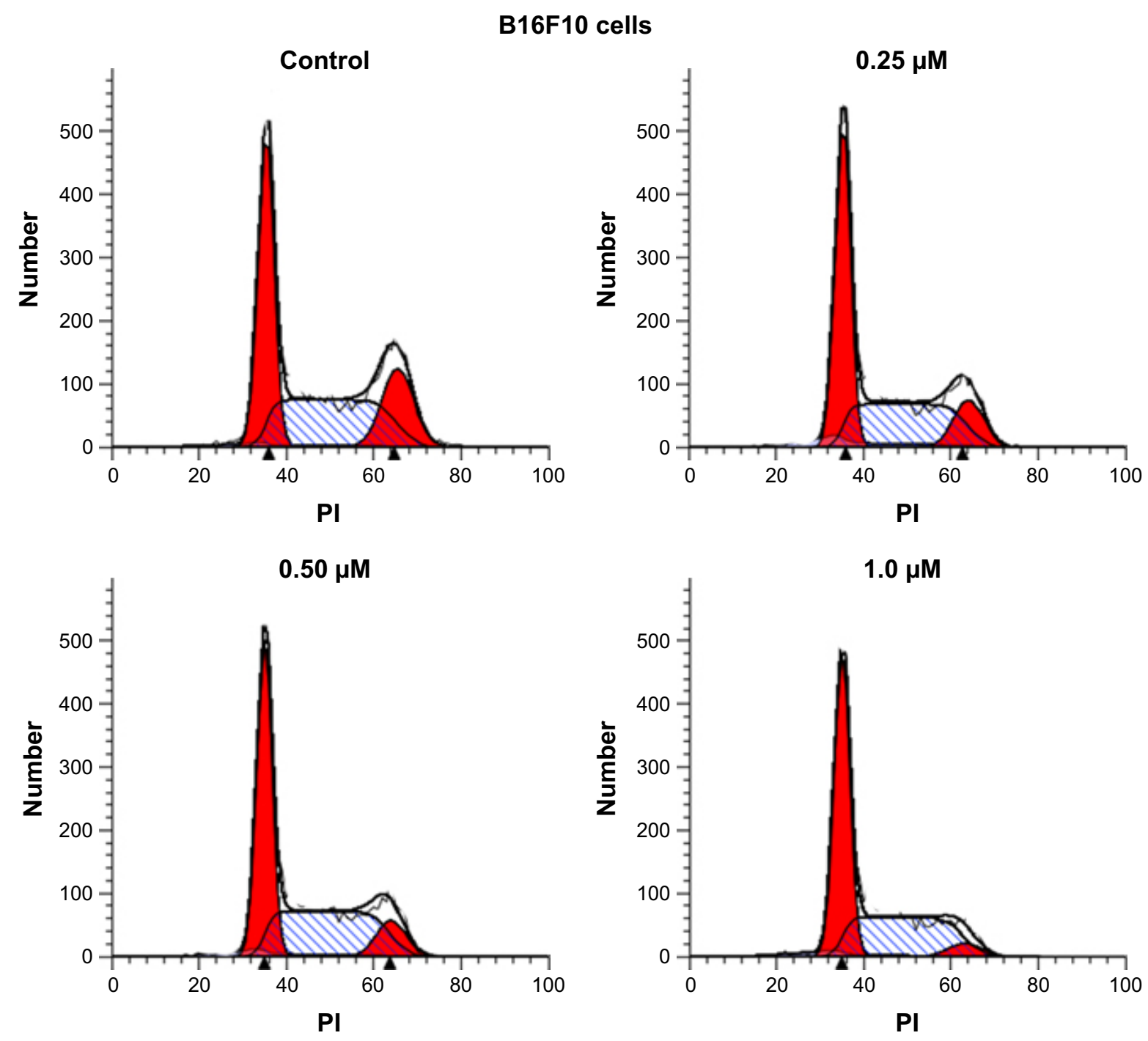

Figure 6 Cell cycle arrest induced by BA-78.

Note: Flow cytometric analysis of control group, BA-78 at $0.25,0.5$ and $1.0 \mu \mathrm{M}$.

Abbreviations: BI6FI0, mouse melanoma cells; BA-78, synthetic route for hybride; PI, propidium iodide.

novel NO-releasing derivative of BA (BA-78) using another kind of NO donors, NONOate. As shown in Figure 2, a number of NONOates-based compounds have been developed as anticancer agents. NONOates release NO spontaneously under physiological conditions $\left(\mathrm{pH} 7.4,37^{\circ} \mathrm{C}\right)$ with a range of half-lives from a few seconds to several days,

Table 3 The influence of cell cycle progression in BI6FIO cells by BA-78 at different concentrations

\begin{tabular}{lllll}
\hline Group & & GI (\%) & S (\%) & G2 (\%) \\
\hline Negative control & & 40.23 & 41.32 & 18.45 \\
BA-78 & $0.25 \mu \mathrm{M}$ & 43.18 & 40.94 & 15.88 \\
& $0.50 \mu \mathrm{M}$ & 46.29 & 43.76 & 9.95 \\
& $1.0 \mu \mathrm{M}$ & 52.06 & 43.10 & 4.84 \\
\hline
\end{tabular}

Abbreviations: BI6FI0, mouse melanoma cells; BA-78, synthetic route for hybride. displaying antithrombotic, vasorelaxant, and cytostatic activities. ${ }^{30}$ The nitrite measured after culture of tumor cells with BA-78 may be generated by at least 2 different modes. These are as follows: 1) oxidation of $\mathrm{NO}$ released from the drug by molecular oxygen, and 2) oxidation of NO by tumor cell catalase. Both processes lead to the generation of nitrite. BA showed moderate cytotoxicity on cancer cells used in our study (17.53-38.30 $\mu \mathrm{M})$, and the connection with NONOate dramatically increased the antiproliferative efficacy of BA-78 $(0.89-7.44 \mu \mathrm{M})$. We attributed this improvement mainly to the NO-releasing ability of BA-78. However, it should be noted that $\mathrm{NO}$ can both promote and inhibit tumor progression and metastasis, this dual nature of $\mathrm{NO}$ is greatly dependent on the dose and duration of NO exposure and cellular sensitivity. ${ }^{31}$ 
Low concentration of $\mathrm{NO}$ can promote invasion and metastases in different tumor models, and high concentration of $\mathrm{NO}$ can inhibit tumor growth and metastases. ${ }^{32,33} \mathrm{NO}$ alone shows a high $\mathrm{IC}_{50}$ concerning its cytostatic efficacy, while the reported anticancer candidates with NO-releasing residue have much lower $\mathrm{IC}_{50}$ (from hundreds nanomoles to several micromoles). It has been reported by Heigold et al that NO induced apoptosis selectively in NOX-expressing transformed cells through formation of peroxynitrite in early stages of carcinogenesis. ${ }^{34}$ Later, it was found that at late stages of tumor progression, membrane-associated catalase protects from apoptosis induced by exogenous NO. ${ }^{35}$ There is a delicate balance between oxidation of $\mathrm{NO} /$ decomposition of peroxynitrite by tumor cell protective catalase and NO-mediated inhibition of catalase. ${ }^{36}$ Besides, it should be kept in mind that the intracellular NO is not always correlated with those obtained in simple phosphate buffer for the sake of cell permeability and tumor microenvironment. In addition, our study showed that BA-78 exerted much higher inhibitory activity against tumor growth than $\mathrm{NO}$, it seems that other features of BA- 87 besides NO release might contribute to its antitumor activity. Many research by us and others have verified these assumptions.

BA was reported to induce apoptosis by damaging the mitochondrial membrane, leading to Cyt-c release into cytosol, which, in turn, regulates the downstream caspase activation. ${ }^{37,38}$ In the present study, we also found the increase in Cyt-c expression in cytosol. Besides, there is a direct relationship between antiproliferative activity of BA and depression of antiapoptotic Bcl-2 family proteins. ${ }^{39} \mathrm{Bcl}-2$ family proteins serve as critical regulators of apoptosis. ${ }^{40,41} \mathrm{As}$ shown in Figure 5, the expression of pro-apoptotic proteins increased with the incubation of BA-78, while the expression of anti-apoptotic proteins significantly decreased. This observation was in line with previous reports. We therefore concluded that BA-78 induced apoptosis through mitochondrial apoptotic pathway.

Mitochondria are the cell's power plant that must be in a proper functional state in order to produce the energy necessary for basic cellular functions, such as proliferation. This is especially the case in fast-growing tumor cells. ${ }^{42}$ Moreover, mitochondrial fission participates in cell mitosis, and dysfunction of mitochondrial function can, no doubt, induce arrest of cell cycle. In this study, we accordingly found that BA-78 induced cell cycle arrest in the G1 phase, which might be ascribed to the dysfunction of mitochondrial dynamics.

\section{Conclusion}

A novel BA/NONOate hybride nominated as BA-78 was designed and synthesized in this research. BA-78 exhibited excellent antiproliferative ability in melanoma B16F10 cells with an $\mathrm{IC}_{50}$ as low as $0.89 \mu \mathrm{M}$. Notably, NO release assay suggested that the potent cytotoxicity of BA-78 was partly attributed to NO produced from NONOate. The anticancer mechanism studies further revealed that the antiproliferative activity of BA-78 was ascribed to the induction of mitochondrial apoptosis and cell cycle arrest in the G1 phase. Taken together, these findings provide a preliminary basis for the rational design and mechanism study of NO-based derivative of BA.

\section{Acknowledgments}

This work was supported by grants from the Outstanding Leaders Training Program of Pudong Health Bureau of Shanghai (NO PWR12015-06, NO PWRd2017-11) and by a program of Shanghai Pudong Hospital (NO 201602), Fudan University. Shanghai Key Laboratory of Bioactive Small Molecules, Department of Pharmacology, School of Pharmacy and Institutes of Biomedical Sciences, Fudan University, Shanghai, China. Laiyin Zhang is the first author for this study.

\section{Disclosure}

The authors report no conflicts of interest in this work.

\section{References}

1. Newman DJ. Developing natural product drugs: supply problems and how they have been overcome. Pharmacol Ther. 2016;162:1-9.

2. Zhou J, Li CJ, Yang JZ, et al. Lupane triterpenoids from the stems of Euonymus carnosus. J Nat Prod. 2014;77(2):276-284.

3. Ye WC, Ji NN, Zhao SX, et al. Triterpenoids from Pulsatilla chinensis. Phytochemistry. 1996;42(3):799-802.

4. Yogeeswari P, Sriram D. Betulinic acid and its derivatives: a review on their biological properties. Curr Med Chem. 2005;12(6):657-666.

5. Zhang DM, Xu HG, Wang L, et al. Betulinic acid and its derivatives as potential antitumor agents. Med Res Rev. 2015;35(6):1127-1155.

6. Zhang X, Hu J, Chen Y. Betulinic acid and the pharmacological effects of tumor suppression (Review). Mol Med Rep. 2016;14(5):4489-4495.

7. Mullauer FB, Kessler JH, Medema JP. Betulinic acid, a natural compound with potent anticancer effects. Anticancer Drugs. 2010;21(3):215-227.

8. Lowenstein CJ, Dinerman JL, Snyder SH. Nitric oxide: a physiologic messenger. Ann Intreern Med. 1994;120(3):227-237.

9. Vasudevan D, Thomas DD. Insights into the diverse effects of nitric oxide on tumor biology. Vitam Horm. 2014;96:265-298.

10. Keefer LK. Nitric oxide (NO)- and nitroxyl (HNO)-generating diazeniumdiolates (NONOates): emerging commercial opportunities. Curr Top Med Chem. 2005;5(7):625-636.

11. Shami PJ, Saavedra JE, Bonifant CL, et al. Antitumor activity of JS-K [O2-(2,4-dinitrophenyl)1-[(4-ethoxycarbonyl)piperazin-1-yl]diazen1-ium-1,2-diolate] and related O2-aryl diazeniumdiolates in vitro and in vivo. J Med Chem. 2006;49(14):4356-4366.

12. Andrei D, Maciag AE, Chakrapani H, Citro ML, Keefer LK, Saavedra JE. Aryl bis(diazeniumdiolates): potent inducers of S-glutathionylation of cellular proteins and their in vitro antiproliferative activities. $J$ Med Chem. 2008;51(24):7944-7952.

13. Cai TB, Tang X, Nagorski J, Brauschweiger PG, Wang PG. Synthesis and cytotoxicity of 5-fluorouracil/diazeniumdiolate conjugates. Bioorg Med Chem. 2003;11(23):4971-4975. 
14. Xu S, Wang G, Lin Y. Novel anticancer oridonin derivatives possessing a diazen-1-ium-1,2-diolate nitric oxide donor moiety: design, synthesis, biological evaluation and nitric oxide release studies. Bioorg Med Chem Lett. 2016;26(12):2795-2800.

15. Medina-O’Donnell M, Rivas F, Reyes-Zurita FJ, et al. Semi-synthesis and antiproliferative evaluation of PEGylated pentacyclic triterpenes. Eur J Med Chem. 2016;118:64-78.

16. Huang Z, Zhang Y, Fang L, et al. Nanometre-sized titanium dioxidecatalyzed reactions of nitric oxide with aliphatic cyclic and aromatic amines. Chem Commun (Camb). 2009;13:1763-1765.

17. Li D, Han T, Tian K, et al. Novel nitric oxide-releasing spirolactonetype diterpenoid derivatives with in vitro synergistic anticancer activity as apoptosis inducer. Bioorg Med Chem Lett. 2016;26(17): 4191-4196.

18. Bobba A, Atlante A, Moro L, Calissano P, Marra E. Nitric oxide has dual opposite roles during early and late phases of apoptosis in cerebellar granule neurons. Apoptosis. 2007;12(9):1597-1610.

19. Kvansakul M, Hinds MG. The Bcl-2 family: structures, interactions and targets for drug discovery. Apoptosis. 2015;20(2):136-150.

20. Pisha E, Chai H, Lee IS, et al. Discovery of betulinic acid as a selective inhibitor of human melanoma that functions by induction of apoptosis. Nat Med. 1995;1(10):1046-1051.

21. Mukherjee R, Kumar V, Srivastava SK, Agarwal SK, Burman AC. Betulinic acid derivatives as anticancer agents: structure activity relationship. Anticancer Agents Med Chem. 2006;6(3):271-279.

22. Khan I, Guru SK, Rath SK, et al. A novel triazole derivative of betulinic acid induces extrinsic and intrinsic apoptosis in human leukemia HL-60 cells. Eur J Med Chem. 2016;108:104-116.

23. Spivak AY, Keiser J, Vargas M, et al. Synthesis and activity of new triphenylphosphonium derivatives of betulin and betulinic acid against Schistosoma mansoni in vitro and in vivo. Bioorg Med Chem. 2014; 22(21):6297-6304.

24. Dutta D, Chakraborty B, Sarkar A, Chowdhury C, Das P. A potent betulinic acid analog ascertains an antagonistic mechanism between autophagy and proteasomal degradation pathway in HT-29 cells. BMC Cancer. 2016;16:23.

25. Nandurdikar RS, Maciag AE, Cao Z, Keefer LK, Saavedra JE. Diazeniumdiolated carbamates: a novel class of nitric oxide donors. Bioorg Med Chem. 2012;20(6):2025-2029.

26. Han C, Huang Z, Zheng C, et al. Novel hybride of (phenylsulfonyl) furoxan and anilinopyrimidine as potent and selective epidermal growth factor receptor inhibitors for intervention of non-small-cell lung cancer. J Med Chem. 2013;56(11):4738-4748.

27. Vannini F, MacKessack-Leitch AC, Eschbach EK, Chattopadhyay M, Kodela R, Kashfi K. Synthesis and anti-cancer potential of the positional isomers of NOSH-aspirin (NBS-1120) a dual nitric oxide and hydrogen sulfide releasing hybrid. Bioorg Med Chem Lett. 2015;25(20): 4677-4682.
28. Fu J, Liu L, Huang Z, et al. Hybrid molecule from O2-(2,4-dinitrophenyl) diazeniumdiolate and oleanolic acid: a glutathione S-transferase $\pi$-activated nitric oxide prodrug with selective anti-human hepatocellular carcinoma activity and improved stability. J Med Chem. 2013;56(11): 4641-4655.

29. Liu JH, Tang J, Zhu ZF, Chen L. Design, synthesis, and anti-tumor activity of novel betulinic acid derivatives. J Asian Nat Prod Res. 2013; 16(1):34-42.

30. Holland RJ, Klose JR, Deschamps JR, Cao Z, Keefer LK, Saavedra JE. Direct reaction of amides with nitric oxide to form diazeniumdiolates. J Org Chem. 2014;79(19):9389-9393.

31. Fukumura D, Kashiwagi S, Jain RK. The role of nitric oxide in tumor progression. Nat Rev Cancer. 2006;6(7):521-534.

32. Rabender CS, Alam A, Sundaresan G, et al. The role of nitric oxide synthase uncoupling in tumor progression. Mol Cancer Res. 2015;13(6) 1034-1043.

33. Ren Z, Gu X, Lu B, et al. Anticancer efficacy of a nitric oxide-modified derivative of bifendate against multidrug-resistant cancer cells. $J$ Cell Mol Med. 2016;20(6):1095-1105.

34. Heigold S, Sers S, Bechtel W, Ivanovas B, Schäfer R, Bauer G. Nitric oxide mediates apoptosis induction selectively in transformed fibroblasts compared to nontransformed fibroblasts. Carcinogenesis. 2002; 23(6):929-941.

35. Heinzelmann S, Bauer G. Multiple protective functions of catalase against intercellular apoptosis-inducing ROS signaling of human tumor cells. Biol Chem. 2010;391(6):675-693.

36. Bauer G. Increasing the endogenous NO level causes catalase inactivation and reactivation of intercellular apoptosis signaling specifically in tumor cells. Redox Biol. 2015;6:357-371.

37. Potzel L, Mullauer FB, Colak S, Kessler JH, Medema JP. Betulinic acid-induced mitochondria-dependent cell death is counterbalanced by an autophagic salvage response. Cell Death Dis. 2014;5:e1169.

38. Liu Y, Luo W. Betulinic acid induces Bax/Bak-independent cytochrome $\mathrm{c}$ release in human nasopharyngeal carcinoma cells. Mol Cells 2012;33(5):517-524.

39. Rzeski W, Stepulak A, Szymański M, et al. Betulinic acid decreases expression of bcl-2 and cyclin D1, inhibits proliferation, migration and induces apoptosis in cancer cells. Naunyn Schmiedebergs Arch Pharmacol. 2006;374(1):11-20.

40. Ashkenazi A, Fairbrother WJ, Leverson JD, Souers AJ. From basic apoptosis discoveries to advanced selective BCL-2 family inhibitors. Nat Rev Drug Discov. 2017;16(4):273-284.

41. Adams JM, Cory S. Bcl-2-regulated apoptosis: mechanism and therapeutic potential. Curr Opin Immunol. 2007;19(5):488-496.

42. Horbay R, Bilyy R. Mitochondrial dynamics during cell cycling. Apoptosis. 2016;21(12):1327-1335 


\section{Supplementary materials}

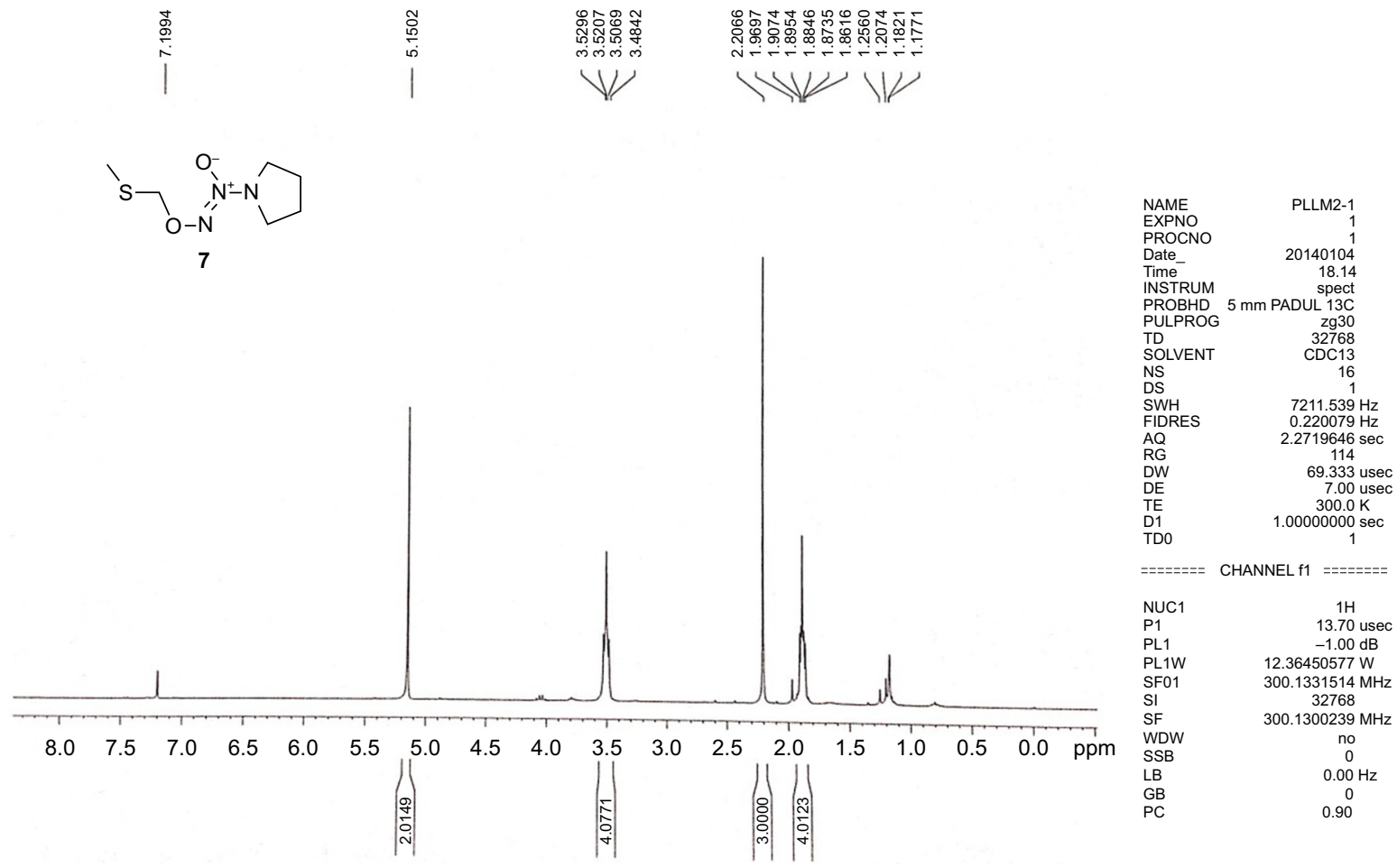

Figure SI The 'H-NMR spectrum of compound 7.

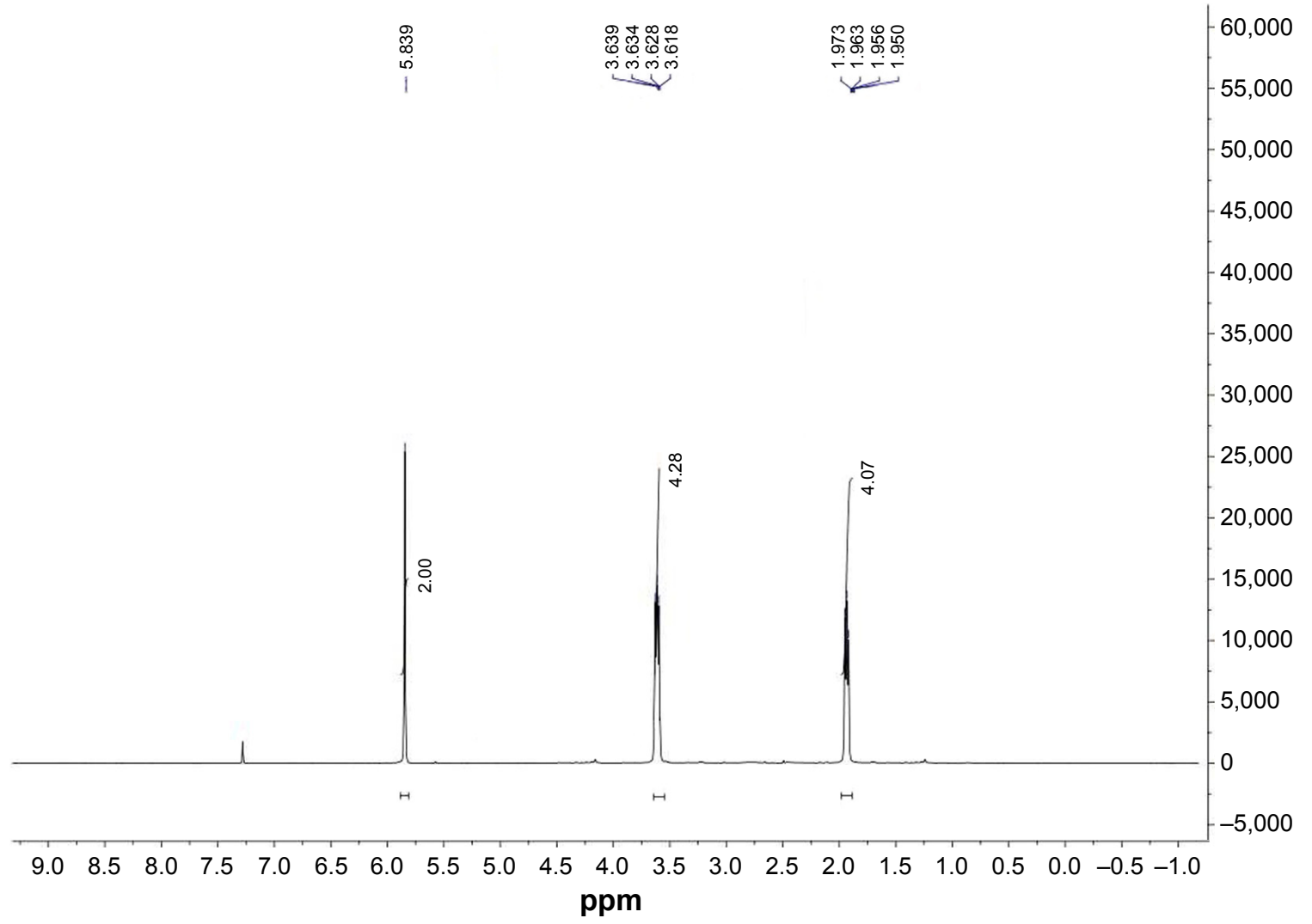

Figure S2 The 'H-NMR spectrum of compound 8. 


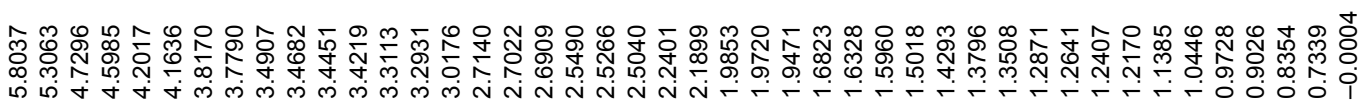
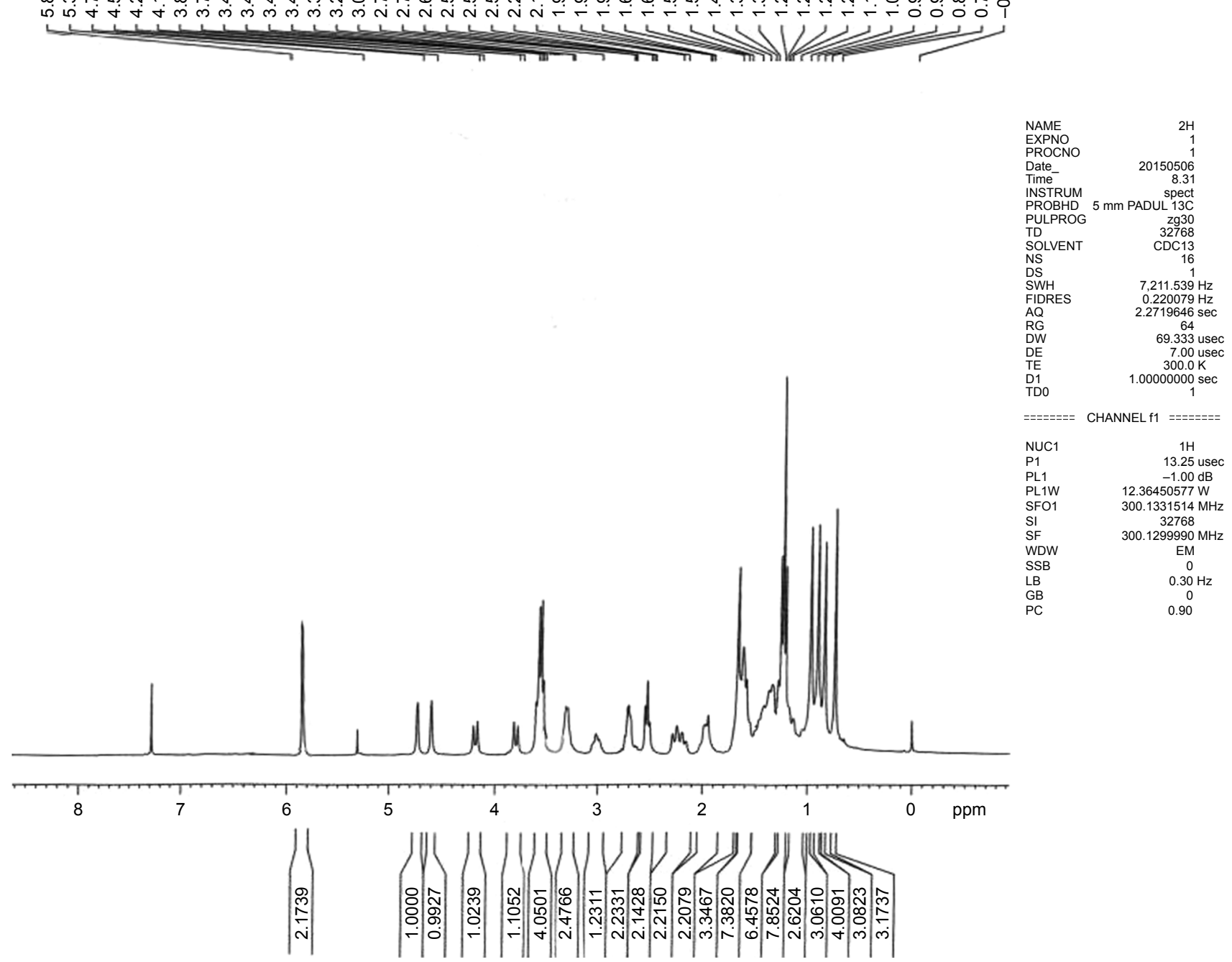

$\begin{array}{lc}\text { NUC1 } & 1 \mathrm{H} \\ \text { P1 } & 13.25 \mathrm{usec} \\ \text { PL1 } & -1.00 \mathrm{~dB} \\ \text { PL1W } & 12.36450577 \mathrm{~W} \\ \text { SFO1 } & 300.1331514 \mathrm{MHz} \\ \text { SI } & 32768 \\ \text { SF } & 300.1299990 \mathrm{MHz} \\ \text { WDW } & \text { EM } \\ \text { SSB } & 0 \\ \text { LB } & 0.30 \mathrm{~Hz} \\ \text { GB } & 0 \\ \text { PC } & 0.90\end{array}$

Figure S3 The 'H-NMR spectrum of compound 10 (BA-78).

\section{Publish your work in this journal}

OncoTargets and Therapy is an international, peer-reviewed, open access journal focusing on the pathological basis of all cancers, potential targets for therapy and treatment protocols employed to improve the management of cancer patients. The journal also focuses on the impact of management programs and new therapeutic agents and protocols on patient perspectives such as quality of life, adherence and satisfaction. The manuscript management system is completely online and includes a very quick and fair peer-review system, which is all easy to use. Visit http://www.dovepress.com/testimonials.php to read real quotes from published authors. 